\title{
DIETARY MODULATION OF IMMUNE RESPONSES BY ASCORBIC ACID IN HEALTHY AND CADMIUM-INDUCED IMMUNOCOMPROMISED CHICKENS
}

\author{
Svetlana Vasiljjeva*, Nadežda Bērziṇa*, and Inesa Remeza** \\ * Institute of Biology, University of Latvia, Miera iela 3, Salaspils LV-2169, LATVIA \\ ** Institute of Occupational and Environmental Health, Rīga P. Stradiṇš Medical University, Dzirciema iela 16, Rīga LV-1007, LATVIA
}

Communicated by Henriks Zenkevičs

\begin{abstract}
The assessment of immunological changes induced in chickens by feeding $50 \mathrm{mg}$ cadmium per $1 \mathrm{~kg}$ of diet from hatching to 30 days of age was studied. Furthermore, the modulatory effects of different supplemental doses of ascorbic acid (100 and $1000 \mathrm{mg}$ per $1 \mathrm{~kg}$ of diet) were investigated. The observed immunocompromise in chickens continuously exposed to cadmium resulted in a decreased growth rate and disturbance of immune responses, both on nonspecific and specific levels. The effect of supplements 100 and $1000 \mathrm{mg}$ of ascorbic acid per $1 \mathrm{~kg}$ of diet differed. The low dosage of ascorbic acid had immunostimulative action in healthy cadmium-untreated chickens, provided correction of compromised immunity, and increased tolerance of the birds to subtoxic cadmium intake. In contrast, the higher supplement of ascorbic acid had a slight or no effect on healthy birds and either caused no significant shifts in immunological indices or manifested synergistic effect combined with cadmium.
\end{abstract}

Key words: cadmium, ascorbic acid, chickens, immunity.

\section{INTRODUCTION}

A wide range of external factors such as environmental contamination, anthropogenic activity, nutritional imbalances and toxicity can affect the health status of human and animals by creating stress to the organism. The heavy metal cadmium $(\mathrm{Cd})$ is a naturally occurring element that is present everywhere in the environment - in almost all soils, surface waters, plants and wildlife (Hutton, 1983, Mochizuki et al., 2002). Cd enters the soil via phosphate fertilizers, sewage slages and air pollutions. It is estimated that about $200 \mathrm{t}$ of Cd enters the Baltic Sea every year (Anonims, 2003). The average contamination of soils by $\mathrm{Cd}$ has increased by about $0.2 \%$ yearly (Järup et al., 1998). A study conducted in the University of Latvia in 2007 indicated that garden soils in Rìga contained $0.1-0.5 \mathrm{mg} \cdot \mathrm{kg}^{-1} \mathrm{Cd}$ (Čekstere, 2011). It is important to monitor the $\mathrm{Cd}$ content in feed and foodstuffs consumed in Latvia. In comparison with other heavy metals, $\mathrm{Cd}$ possesses high mobility in soil and is taken up in plants in various degrees. Cd intake by humans occurs mainly via the food chain and this heavy metal is considered one of the most dangerous occupational and environmental poisons. Hazards from $\mathrm{Cd}$ are associated with its high bioaccumulative capacity and prolonged biological half-life, which in human kidney has been estimated to be 18 to 33 years or longer (Fox, 1979). The adverse human and animal health effects of $\mathrm{Cd}$ are numerous (Bokori and Fekete, 1995, Chan et al., 2004, Järup, 2003, Satoh et al., 2002, Sellin et al., 2007). However, several studies have documented an effect of $\mathrm{Cd}$ on the immune system, which was either stimulatory or inhibitory, depending on the species, dose, route and time exposure (Hill, 1979, Chowdhury et al., 1987). Although the results are somewhat ambiguous, $\mathrm{Cd}$ is believed to be generally immunosuppressive. Excessive $\mathrm{Cd}$ intake and its accumulation in tissues accelerates metabolic processes and may exert a toxic effect via oxidation damage to cellular organelles by inducing the generation species of reactive oxygen that attack cell lipid membranes, proteins, and DNA within the nucleous of cells (Stohls et al., 2000). A disbalanced antioxidant system and developed antioxidant stress produce damage to healthy tissues and immune cells by free radicals, which results in compromised immune function.

Since Cd-induced damage in an organism is believed to be irreversible, the question of primary prevention is of great importance. Efficient beneficial results may be achieved by addition of nutrients with antioxidative properties to the diet. Antioxidants are known to play a vital role in the immune system and health due to cell protection from damage induced by oxidative stress (Surai, 2003). One of the most effective substances possessing high free radical scavenging activity is ascorbic acid (AA). Therefore, the requirement of an organism for vitamin $\mathrm{C}$ can increase in case of any stressful condition ( $\mathrm{Yu}, 1994)$, including Cd toxicity (Fox and Fry, 1970, Ogungbe and Lawal, 2008). Furthermore, despite the capacity of birds to synthesize AA, its endogeneous production in young chickens is believed to be in- 
sufficient (Вальдман, 1977). The increased utilisation of endogenous antioxidants can be replenished by dietary supplements of AA. However, as reported in our former study, the observed dual (anti- and prooxidant) effect of AA depends on the supplemented dose employed (Berzina et $a l ., 2005)$. Taking the above mentioned into account, chicken can be chosen as an adequate model to study the efficiency of AA as an immuno-modulating nutrient during heavy metal exposure. For a more complete understanding of avian immune response on $\mathrm{Cd}$ action and the possible modulatory effect of ascorbic acid supplements to the diet, further work is needed. In this regard, the present study was aimed to investigate how long-term exposure of chickens to a dietary subtoxic dose of $\mathrm{Cd}$ results in nonspecific and specific defense mechanisms, and to evaluate the effect of different doses of ascorbic acid on Cd-induced changes in the immune system.

\section{MATERIALS AND METHODS}

For use in the experiment, newly hatched male Lohmann brown chickens were obtained from SIA BALTICOVO (Iecava, Latvia). The experiment was started on the same day and terminated on day 30. Food and water were provided $a d$ libitum. A standard fool-fed basal diet consisted of $47 \%$ barley, 29\% wheat, 19\% soya, and 5\% protein-vitaminmineral premix “Stimovits” (SIA „Stepo”, Latvia). The used premix contained all necessary vitamins except vitamin C. Vitamin $\mathrm{C}$ was not added to achieve a minimal content in diet $(0.5 \mathrm{mg} / \mathrm{kg})$. The diet contained a trace level $(0.2$ $\mathrm{mg} / \mathrm{kg}$ ) of $\mathrm{Cd}$. The birds were divided into six groups of 20 heads in each and assigned to the following diets. Group 1 (control) was fed the basal diet. Groups 2 (AA 100) and 3 (AA 1000) were given the same diet, but supplemented with AA (100 and $1000 \mathrm{mg} / \mathrm{kg}$, respectively). The next three groups of chickens received the same diet with addition of $50 \mathrm{mg} \mathrm{Cd} / \mathrm{kg}$ (as $\mathrm{CdCl}_{2}$, Sigma, EU): group $4(\mathrm{Cd})$, group 5 $(\mathrm{Cd}+\mathrm{AA} 100)$, and group $6(\mathrm{Cd}+\mathrm{AA} 1000)$. In our experiment a subtoxic dose of Cd was chosen (Anonymous, 1984; Bokori and Fekete, 1995).

Immunisation with sheep red blood cells (SRBC) was performed to induct chicken immune responsiveness. Seven and six days before the end of the experiment, ten birds from each group twice were immunised by intraperitoneal injection with $0.1 \mathrm{ml}$ of $10 \%$ SRBC suspension (Government National Diagnostical Centre of Products and Veterinary Service, Laboratory of Serology).

At the end of experimental period, the chickens were weighed individually and decapitated by guillotine according the recommendation for the Euthanasia of Experimental Animals of the European Convention (Close et al., 1997). Peripheral blood samples and immunocompetent organs were taken for analyses.

Haemoglobin $(\mathrm{Hb})$ level was estimated by cyanohaemoglobin method with a commercial kit (SIA“Divi-Dent", Latvia). Blood smears were used to establish total erythrocyte and leukocyte count by light microscope. Serum antibody titres against SRBC were measured by a direct haemagglutination assay (Friemel, 1976). Serum lysozyme content was evaluated by nefelometric assay (Shugar, 1952) with some modification, by absorptiometric determination of the decrease in turbidity of a suspension of Micrococcus lysodeicticus. Nonspecific circulating immune complexes (CIC) in serum were estimated spectrophotometrically using precipitation with polyethylenglycol 6000 (Riha, 1979). The central immune organs, thymus and bursa of Fabricius, and peripheral spleen were dissected and weighed. The organ weight relative to body weight was calculated. Phagocytic cell activity in spleen was estimated using a light microscope by counting number of phagocytizing cells (macro- and microphages, heterophils) with engulfed zymozan granules (Федосеева и др., 1993). A detailed descripton of the majority of methods employed in the experiment with some modifications is presented in Васильева и др. (2001).

Statistical significance was evaluated by the Student's t-test. Differences were considered significant at $P<0.05$.

\section{RESULTS}

Chickens exposed to $50 \mathrm{mg} / \mathrm{kg} \mathrm{Cd}$ showed no evidence of clinical toxicity, but some features of adverse action of this heavy metal on bird health were observed. After 30 days of $\mathrm{Cd}$ treatment, chicken body weight in the $\mathrm{Cd}$ group decreased by $46.4 \%(P<0.05)$ compared to healthy control chickens (Table 1). The most sensitive immune organ influenced by $\mathrm{Cd}$ in these chickens was bursa of Fabricius, the relative weight of which was by $40 \%$ lower compared to the control $(P<0.05)$. Less $\mathrm{Cd}$ impact on thymus and spleen was observed. These features were accompanied by a change of haematological parameters and immune indices. Haematological examination (Table 2) demonstrated that, in comparison to controls, haemoglobin level and erythrocyte number were lower in Cd-exposed chickens. The erythrocyte number decreased to $2.6 \cdot 10^{12} \cdot 1^{-1}$ (normal level is $3.6-3.8 \cdot 10^{12} \cdot 1^{-1}$ ), while total leycocyte count had a tendency to increase under $\mathrm{Cd}$ influence. Suppressive $\mathrm{Cd}$ action on chicken immune response was manifested by a decrease of spleen phagocytic activity (Fig. 1) and disturbunce of nonspecific humoral chicken immune indices - decrease of serum lysozyme and increase of CIC content (Fig. 2). On the other hand, specific antibody response against SRBC in chickens exposed to Cd significantly increased (Fig. 3). The action of dietary supplements of AA in experimental chicken groups depended on the AA dose and $\mathrm{Cd}$ intake. AA addition to the basal diet at both dosages (100 and 1000 $\mathrm{mg} / \mathrm{kg}$ ) without $\mathrm{Cd}$ induced a raised chicken body weight compared to the control (see Table 1). However, when chickens were exposed to $\mathrm{Cd}$ the effect of the AA dietary doses differed. Compared to the control, body weight was higher by $17.6 \%(P<0.05)$ when $\mathrm{AA}(100)$ was added to the diet, while the AA(1000) supplementation did not prevent inhibitory action of $\mathrm{Cd}$ on growth. No significant change in relative weights of immunocompetent organs was 
EFFECT OF ASCORBIC ACID ON BODY WEIGHT AND RELATIVE WEIGHT OF IMMUNE ORGANS IN 30-DAY-OLD CHICKENS FED DIETS WITH AND WITHOUT ADDED CADMIUM

\begin{tabular}{|c|c|c|c|c|c|}
\hline \multirow[t]{2}{*}{ Group Nr. } & \multirow[t]{2}{*}{ Diet type } & \multirow[t]{2}{*}{ Body weight, $g$} & \multicolumn{3}{|c|}{$\begin{array}{c}\text { Relative weight of organ, } \\
\text { g/100g body weight }\end{array}$} \\
\hline & & & thymus & bursa of Fabricius & spleen \\
\hline 1 & Control & $326.47 \pm 10.15^{b}$ & $0.65 \pm 0.06$ & $0.43 \pm 0.04^{b}$ & $0.19 \pm 0.02$ \\
\hline 2 & $\mathrm{AA}(100)$ & $342.87 \pm 13.18^{b}$ & $0.65 \pm 0.09$ & $0.45 \pm 0.08^{b}$ & $0.19 \pm 0.03$ \\
\hline 3 & $\mathrm{AA}(1000)$ & $343.70 \pm 12.78^{b}$ & $0.71 \pm 0.05^{b}$ & $0.49 \pm 0.05^{b}$ & $0.21 \pm 0.03$ \\
\hline 4 & $\mathrm{Cd}$ & $207.60 \pm 9.08^{a}$ & $0.60 \pm 0.03$ & $0.26 \pm 0.02^{\mathrm{a}}$ & $0.18 \pm 0.02$ \\
\hline 5 & $\mathrm{Cd}+\mathrm{AA}(100)$ & $265.10 \pm 11.10^{\mathrm{ab}}$ & $0.63 \pm 0.05$ & $0.31 \pm 0.03^{a}$ & $0.19 \pm 0.02$ \\
\hline 6 & $\mathrm{Cd}+\mathrm{AA}(1000)$ & $208.97 \pm 10.14^{\mathrm{a}}$ & $0.51 \pm 0.02^{\mathrm{ab}}$ & $0.30 \pm 0.04^{\mathrm{a}}$ & $0.17 \pm 0.03$ \\
\hline
\end{tabular}

Control - chickens were fed a basal standard diet; AA(100) and AA(1000) groups of chickens fed diets supplemented with $100 \mathrm{mg} / \mathrm{kg}$ and $1000 \mathrm{mg} / \mathrm{kg}$ of ascorbic acid, correspondingly; $\mathrm{Cd}$ - group of chickens fed a diet with added $50 \mathrm{mg} / \mathrm{kg} \mathrm{Cd}($ as $\mathrm{CdCl} 2)$; $\mathrm{Cd}+\mathrm{AA}(100)$ and $\mathrm{Cd}+\mathrm{AA}(1000)$ groups of chickens fed diets supplemented with $50 \mathrm{mg} / \mathrm{kg} \mathrm{Cd}\left(\right.$ as $\left.\mathrm{CdCl}_{2}\right)$ and $100 \mathrm{mg} / \mathrm{kg}$ and $1000 \mathrm{mg} / \mathrm{kg}$ of ascorbic acid, correspondingly.

${ }^{\text {a }}$ Statistically different from the $1^{\text {st }}$ group $(P<0.05)$

${ }^{\text {b }}$ Statistically different from the $4^{\text {th }}$ group $(P<0.05)$

Table 2

HAEMATOLOGICAL INDICES IN CHICKENS AFTER CONSUMPTION OF DIETS SUPPLEMENTED WITH ASCORBIC ACID AND CADMIUM

\begin{tabular}{c|c|c|c|c}
\hline $\begin{array}{c}\text { Group } \\
\text { Nr. }\end{array}$ & Diet type & $\begin{array}{c}\text { Haemoglobin, } \\
\mathrm{g} \%\end{array}$ & $\begin{array}{c}\text { Total erythro- } \\
\text { cyte count, } \\
10^{12} \cdot 1^{-1}\end{array}$ & $\begin{array}{c}\text { Total leukocyte } \\
\text { count, } \\
10^{9} \cdot 1^{-1}\end{array}$ \\
\hline 1. & Control & $8.26 \pm 0.40^{\mathrm{b}}$ & $3.71 \pm 0.19^{\mathrm{b}}$ & $33.20 \pm 2.10$ \\
2. & $\mathrm{AA}(100)$ & $8.18 \pm 0.36$ & $3.89 \pm 0.15^{\mathrm{b}}$ & $34.00 \pm 3.08$ \\
3. & $\mathrm{AA}(1000)$ & $7.98 \pm 0.31$ & $3.63 \pm 0.21^{\mathrm{b}}$ & $32.00 \pm 0.53$ \\
4. & $\mathrm{Cd}$ & $7.51 \pm 0.27^{\mathrm{a}}$ & $2.60 \pm 0.12^{\mathrm{a}}$ & $35.90 \pm 2.05$ \\
5. & $\mathrm{Cd}+\mathrm{AA}(100)$ & $7.79 \pm 0.29$ & $3.24 \pm 0.22^{\mathrm{ab}}$ & $34.30 \pm 2.62$ \\
6. & $\mathrm{Cd}+\mathrm{AA}(1000)$ & $7.35 \pm 0.33^{\mathrm{a}}$ & $2.92 \pm 0.30^{\mathrm{a}}$ & $30.10 \pm 2.25$
\end{tabular}

Control - chickens were fed a basal standard diet; AA(100) and AA(1000) groups of chickens fed diets supplemented with $100 \mathrm{mg} / \mathrm{kg}$ and 1000 $\mathrm{mg} / \mathrm{kg}$ of ascorbic acid, correspondingly; $\mathrm{Cd}$ - group of chickens fed a diet with added $50 \mathrm{mg} / \mathrm{kg} \mathrm{Cd}$ (as $\mathrm{CdCl}_{2}$ ); $\mathrm{Cd}+\mathrm{AA}(100)$ and $\mathrm{Cd}+\mathrm{AA}(1000)$ groups of chickens fed diets supplemented with $50 \mathrm{mg} / \mathrm{kg} \mathrm{Cd}\left(\right.$ as $\left.\mathrm{CdCl}_{2}\right)$ and $100 \mathrm{mg} / \mathrm{kg}$ and $1000 \mathrm{mg} / \mathrm{kg}$ of ascorbic acid, correspondingly.

a Statistically different from the $1^{\text {st }}$ group $(P<0.05)$

${ }^{\mathrm{b}}$ Statistically different from the $4^{\text {th }}$ group $(P<0.05)$

observed after AA consumption, both in healthy and Cdtreated birds. An exception was observed in chickens that received $\mathrm{Cd}$ and the high $\mathrm{AA}(1000)$ dose, where the relative weight of thymus was reduced by $28.2 \%$ compared to the Cd group $(P<0.05)$ and by $21.5 \%$ compared to the control $(P<0.05)$.

In healthy Cd-untreated chickens, red blood cell parameters, haemoglobin level and erythrocyte number, were slightly altered by experimental doses of AA supplemented alone (see Table 2). The marked Cd-induced decrease of these indices was prevented by $100 \mathrm{mg} / \mathrm{kg}$ AA supplementation. However, no protective action of a higher dose of AA was seen. Regarding white blood parameters, statistically nonsignificant deviations in leukocyte number occured between the experimental groups $(P>0.05)$. However, it should be

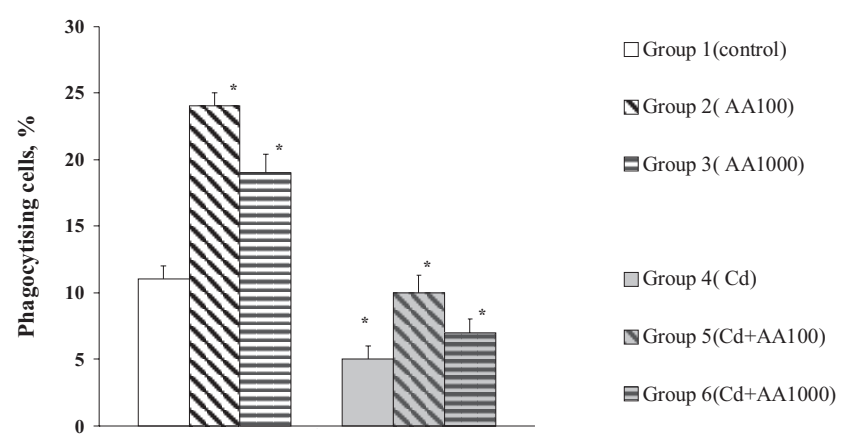

Fig. 1. Phagocytosis of spleenic cells in chickens exposed to cadmium and fed diets supplemented the ascorbic acid. Control - chickens fed the basal standard diet; AA(100) and AA(1000) groups of chickens fed diets supplemented with $100 \mathrm{mg} / \mathrm{kg}$ and $1000 \mathrm{mg} / \mathrm{kg}$ of ascorbic acid, correspondingly; $\mathrm{Cd}$ - group of chickens fed a diet with added $50 \mathrm{mg} / \mathrm{kg} \mathrm{Cd}\left(\right.$ as $\mathrm{CdCl}_{2}$ ); $\mathrm{Cd}+\mathrm{AA}(100)$ and $\mathrm{Cd}+\mathrm{AA}(1000)$ groups of chickens fed diets supplemented with $50 \mathrm{mg} / \mathrm{kg} \mathrm{Cd}\left(\right.$ as $\left.\mathrm{CdCl}_{2}\right)$ and $100 \mathrm{mg} / \mathrm{kg}$ and $1000 \mathrm{mg} / \mathrm{kg}$ of ascorbic acid, correspondingly. ${ }^{*}$ Statistically different from the control $(P<$ $0.05)$

noted that the largest leukocyte number was observed in Cd-exposed chickens. AA(1000) supplementation in both trials provided a similar depressive leukocyte response. The nonspecific immune cellular response is shown in Figure 1. Supplementary intake of AA(100) and AA(1000) caused elevated phagocytic activity in spleen of healthy Cd-untreated chickens. An AA effect was distinguished in the case of $\mathrm{Cd}$ administration. The suppressive $\mathrm{Cd}$ impact was almost reversed by AA(100) supplementation — phagocytosis intensity was similar to that in the control, whereas the effect of $\mathrm{AA}(1000)$ was found minor. Figure 2 illustrates the response of chicken nonspecific humoral immunity on $\mathrm{Cd}$ exposure and addition of AA to the diet. Compared with Cd-untreated control animals, no significant difference in serum lysozyme occured in birds fed a diet with $\mathrm{AA}(100)$, but the level was reduced by $19.1 \%(P<0.05)$ with intake of higher AA. The suppression of lysozyme activity by $\mathrm{Cd}$ was not apparent when the diet was supplemented with 


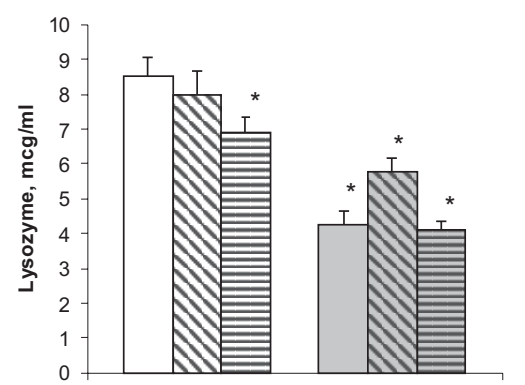

$\square$ Group 1(control)

बGroup 2(AA100)

曰Group 3( AA1000)

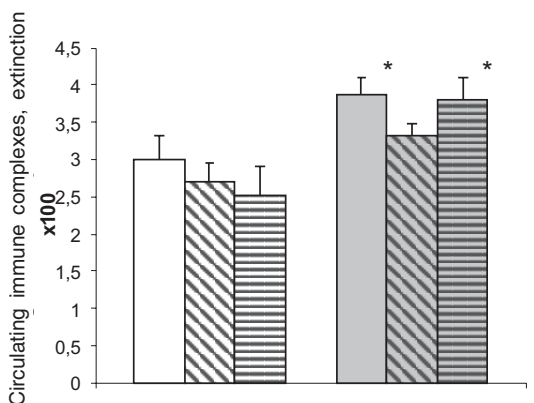

$\square$ Group 4(Cd)

వGroup 5( Cd+AA100)

目Group 6(Cd+AA1000)

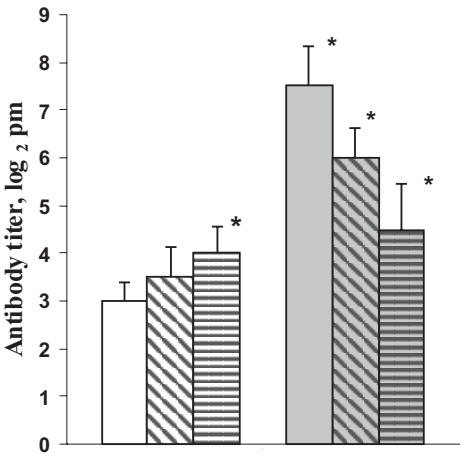

$\square$ Group 1(control)

DGroup 2(AA100)

曰Group 3(AA1000)

$\square$ Group 4(Cd)

\$Group 5( Cd+AA100)

目Group 6(Cd+AA1000)

Fig. 3. The effect of cadmium and ascorbic acid on the humoral antibody response against sheep red blood cells in chickens. Control - chickens were fed a basal standard diet; $\mathrm{AA}(100)$ and $\mathrm{AA}(1000)$ groups of chickens fed diets supplemented with $100 \mathrm{mg} / \mathrm{kg}$ and $1000 \mathrm{mg} / \mathrm{kg}$ of ascorbic acid, correspondingly; $\mathrm{Cd}$ - group of chickens fed a diet with added $50 \mathrm{mg} / \mathrm{kg}$ $\mathrm{Cd}$ (as $\left.\mathrm{CdCl}_{2}\right) ; \mathrm{Cd}+\mathrm{AA}(100)$ and $\mathrm{Cd}+\mathrm{AA}(1000)$ groups of chickens fed diets supplemented with $50 \mathrm{mg} / \mathrm{kg} \mathrm{Cd}\left(\mathrm{as} \mathrm{CdCl}_{2}\right)$ and $100 \mathrm{mg} / \mathrm{kg}$ and 1000 $\mathrm{mg} / \mathrm{kg}$ of ascorbic acid, correspondingly. Statistically different from the control $(P<0.05)$

Fig. 2. Response of nonspecific humoral immunity indices serum lysozyme and circulating immune complexes on cadmium exposure and ascorbic acid supplementation in chickens. Control - chickens were fed a basal standard diet; $\mathrm{AA}(100)$ and $\mathrm{AA}(1000)$ groups of chickens fed diets supplemented with $100 \mathrm{mg} / \mathrm{kg}$ and $1000 \mathrm{mg} / \mathrm{kg}$ of ascorbic acid, correspondingly; $\mathrm{Cd}$ - group of chickens fed a diet with added $50 \mathrm{mg} / \mathrm{kg} \mathrm{Cd}$ (as $\left.\mathrm{CdCl}_{2}\right) ; \mathrm{Cd}+\mathrm{AA}(100)$ and $\mathrm{Cd}+\mathrm{AA}(1000)$ groups of chickens fed diets supplemented with $50 \mathrm{mg} / \mathrm{kg} \mathrm{Cd}\left(\right.$ as $\mathrm{CdCl}_{2}$ ) and $100 \mathrm{mg} / \mathrm{kg}$ and 1000 $\mathrm{mg} / \mathrm{kg}$ of ascorbic acid, correspondingly. "Statistically different from the control $(P<0.05)$

AA(100). However, AA(1000) had no significant effect on this immune response. The level of nonspecific antigen-antibody circulating complexes in blood serum of Cd-untreated chickens showed a tendency to decrease at both doses of AA intake. Cd exposure caused an increase in serum CIC content by $29.3 \%(P<0.05)$ compared to the control. The enrichment of the Cd-containing diet by $\mathrm{AA}(100)$ markedly diminished this value, but AA(1000) did not show this effect. Regarding specific humoral immune response, there was an effect of supplemented AA doses on antibody production to SRBC in healthy chickens, compare to Cdexposed birds (see Fig. 3). Antibody titres against SRBC in Cd-exposed chickens were higher than in healthy untreated animals. The most noticeable increase of antibody response was observed after $\mathrm{Cd}$ treatment alone. AA supplementation resulted in a decrease of this parameter, particularly with supplementation by $\mathrm{AA}(1000)$. In contrast, the consumption of both AA-supplemented diets without $\mathrm{Cd}$ tended to promote chicken specific immune response compared to the control.

\section{DISCUSSION}

The results showed that, in spite of the absence of clinical toxicity manifistation, chicken exposure to a diet supplemented with $50 \mathrm{mg} / \mathrm{kg} \mathrm{Cd}$ for 30 days had a pronounced suppressive effect on animal growth. Supplementation of
$\mathrm{AA}(100)$ to the diet tended promote growth when given in combination with $\mathrm{Cd}$ or alone. AA(1000) did not have an effect on body weight in chickens when added together with $\mathrm{Cd}$. Moreover, the depressive influence of $\mathrm{Cd}$ on thymus relative weight declined with a higher dose of AA. This might suggest a more sensititive response of cell-mediated immunity to combined intake of $\mathrm{Cd}$ with a AA high dose.

Chronic exposure to subtoxic $\mathrm{Cd}$ dose may alter haemopoiesis and immune response in chickens both on nonspecific and specific levels. The observed changes in red blood parameters indicated the harmful action of $\mathrm{Cd}$ on erythrocytes. The observed decrease of erythrocyte number may be accociated with a direct damaging effect of $\mathrm{Cd}$ on red cells. $\mathrm{Cd}$ can accumulate in erythrocytes and affect membrane structure by promoting lipid peroxidation and inhibiting enzymes involved in the removal of specific activated oxygen species (Järup et al., 1998). The data obtained show that both tested dietary AA doses improved red blood parameters, but the modulatory effect of $\mathrm{AA}(1000)$ was slighter than that of $\mathrm{AA}(100)$. The changes in haemoglobin content of examined chickens mainly coincided with the direction of erythrocyte response. Fox and Fry (1970) described a similar. They observed that dietary ascorbic acid supplements had a protective effect from anemia and growth depression produced in young Japanese quail that receiving 75 ppm $\mathrm{Cd}$ in the diet. It appears that the primary observed effect of AA was to improve iron absorption (Fox, 1979; Berzina et al., 2008). It is known that white blood cells, leukocytes, are involved and participate in the development of the immune response. These cells are the effector cells in both specific and nonspesific immune responses (Fairbrother et al., 2004). The observed higher leukocyte counts in Cd-treated chickens may be caused by a stressful effect induced by this heavy metal. The content of AA in white blood cells is also quite high (Beisel, 1982). Maxwell and Robertson (1998) reported that heterophil leukocyte num- 
bers increased during mildly or moderately stressful conditions in poultry. In an experiment on Cd-exposed male rats $\left(5 \mathrm{mg} / \mathrm{kg}\right.$ body weight, $\left.1 / 15 \mathrm{LD}_{50}\right) \mathrm{Cd}$ treatment significantly decreased plasma total protein, blood haemoglobin and total erythrocyte count, while it increased total leukocyte counts (El-Demerdash, et al., 2004). Such deviations in animal blood indices may be produced by $\mathrm{Cd}$-induced oxidative stress in tissues (Berzina et al., 2005). The absence of a beneficial effect of $\mathrm{AA}(1000)$ on haematological parameters of $\mathrm{Cd}$-treated chickens allows to speculate about a synergistic action of $\mathrm{Cd}$ and $\mathrm{AA}$ at this higher dose, i.e. a possible prooxidant effect of AA(1000).

Native defence mechanisms are very important for maintaining animals healthy. If such defensive function is disrupted for any reason, animals become more susceptible to infections. Nonspecific immune response is the first line of defence against many pathogens. One of the nonspecific defense mechanisms is phagocytosis. Cells involved in this immune response include natural killer cells, macrophages, monocytes and neutrophils (or heterophils in birds). Tissue macrophages can phagocytose many particles, including bacteria, which leads to their lysis and inactivation. Alteration in phagocytic activity is an important potentially adverse effect of $\mathrm{Cd}$ on the immune system. The significant inhibition of phagocytosis in spleen cells of Cd-exposed chickens may be mostly due to the high accumulation of $\mathrm{Cd}$ in spleen followed by production of reactive oxygen species and cell damage (Vasilyeva et al., 2004). In the present study, the protective effect of AA(100) supplementation observed in Cd-exposed chickens was likely due to antioxidative properties of AA. Phagocytic activity was also promoted when AA was added to the diet alone. Phagocytosis may be specifically affected by the availability of vitamins, such as vitamin $\mathrm{C}$, which plays an important role in phagocytic cell function (Turgeon, 2003). Ascorbic acid may influence phagocyte mobility by direct effect on the production of the microtubular structures of these cells (Beisel, 1982). Also, in vitro experiments have provided considerable evidence of interaction between vitamin $\mathrm{C}$ and phagocytic cells (leucocyte) (Thomas and Holt, 1978). Moreover, ascorbate and dehydroascorbate have been observed to be utilized during phagocytosis by neutrophils from scorbutic gyinea pigs under in vitro conditions (Stankova et al., 1975).

The innate immune system, or nonspecific immune response, consists of physical barriers, humoral factors, and cellular response. We did not examine the known nonspecific defense factors, such as complement, interferon, lymphokins, properdin etc., but rather, we chose the investigation of chicken humoral immune indices - lysozyme and circulating immune complexes in blood serum. These parameters can be determined using convenient modified methods with sufficient accuracy and sensitivity, and can serve as fast estimate of nonspecific immune responses alterations in chickens. Humoral factors are an integral and important part of innate immunity. The phagocytizing cells contain various lysosomal enzymes, including lysozyme, an integral humoral factor of nonspecific immunity. Lysozyme is of vital importance as a protein and is capable of exerting antimicrobial activity within phagosomes. Lysozyme occurs not only within the granules of neutrophils and macrophages but also in body fluids. It is released from macrophages and participates in the last stage of phagocytosis by disrupting the peptidoglycan layer of bacteria. Stressful conditions may decrease ability of cells to phagocytise, resulting in the reduction of secreted lytic enzymes levels. This mechanism can explain the decrease of serum lysozyme content in chickens during $\mathrm{Cd}$ stress, and its restoration under the protective effect of AA(100). Circulating immune complexes are one of the immunological markers that may be associated with the pathogenesis. A noncovalent combination of antigen with its respective antibody results in the formation of immune complexes. CIC also most likely represent auto antibodies or the reaction of denaturated self proteins, microbes, normal lymphocytes, and nuclear antigens. This phenomenon is usually a protective mechanism for neutralisation and eventual elimination of antigens and some pathogens. CIC are normally removed by mononuclear phagocytic cells. However, CIC formation or their defective clearance under certain circumstances may become detrimental, resulting in pathological deposition in tissues. Further, this can lead to inflammation and cell damage. The evaluation of CIC level in blood serum, as measured by an antigen-non-specific assay, which utilized polyethylenglycol insolubation, may be used as one of markers for immunopathological response of chickens exposed to heavy metal $\mathrm{Cd}$. Some studies have documented the role of CIC as a modulator of both cellular and humoral immune response (Khanna and Karjodkar, 2006). Therefore, pathologically elevated CIC can cause a suppression of cellmediated immunity and modulation of humoral response. The increase of nonspecific CIC in chickens exposed to $\mathrm{Cd}$ indicated an inhibited immune response that remained almost unchanged when AA(1000) was supplemented. However, as observed for phagocytosis, the lower AA(100) corrected this defensive process. In contrast, in healthy chickens both AA doses manifested a beneficial effect.

Specific humoral antibody response against SRBC in chickens treated with $\mathrm{Cd}$ alone appeared to be the highest in the examined groups. This probably is not an evidence of a stimulatory effect of $\mathrm{Cd}$ on immune response, because the other determined parameters of immune response indicated a suppressive $\mathrm{Cd}$ effect. This difference may be due to long-term exposure to the metal and trigger of a compensatory effect during 30 days of the trial. Previuos research has shown an immunosuppressive and toxic effect of Cd. However, direct (spontaneous) Cd action on immunity depends not only on the used dose, but on duration of exposure and other experimental factors. One of the causative factors may be the time of $\mathrm{Cd}$ exposure in relation to the antigen. It was reported that $\mathrm{Cd}$ administration initiated seven days before antigen injection in rats suppressed antibody synthesis, but Cd showed an enhanced response when initiated 14 days earlier (Jones et al., 1971). In our experiment, the immunisation of chickens with SRBC was carried out after 23 days 
of initiatial exposure to $\mathrm{Cd}$. This long chronic period of $\mathrm{Cd}$ loading before antigen administration may indicate the physiological and immunological ability of chicken to respond and adapt to this stressor (Butcher and Miles, 2002). Vitamin C is considered to be a powerful "anti-stress" vitamin and is required in enhanced amounts under stressful conditions. In present study, AA supplements to the diet together with excessive amounts of $\mathrm{Cd}$ were beneficial in helping to alleviate stress. $\mathrm{AA}(100)$ and to a great extent $\mathrm{AA}(1000)$, tended to moderate the increase of SRBC antibodies, and corrected the Cd-induced disturbance of immune response in this stage. Conversely, the effect of the tested AA doses supplemented to the diet of Cd-untreated chickens showed a tendency to stimulate antibody-mediated humoral response compare to the control. This indicates a beneficial nutritional effect of AA in modification of SRBC antibody production in healthy chickens.

In conclusion, the results of the present study indicate that dietary intake of a subtoxic Cd level $(50 \mathrm{mg} / \mathrm{kg})$ in chickens during continuous exposure for 30 days had an immunosuppressive effect, without evidence of clinical toxicity. A compromise to chicken welfare was manifested by a decrease of growth rate and relative weight of central immunocompetent organs bursa of Fabricius and thymus, and changes in the immune responses both on nonspecific and specific levels. Treatment with $\mathrm{Cd}$ caused contrasting changes in red and white blood parameters: erythrocyte number and haemoglobine content tended to decrease, while total leukocyte counts insignificantly increased. $\mathrm{Cd}$ induced a suppressive effect on nonspecific humoral and cellular immune response, resulting in reduction of serum lysozyme content, increase of circulating immune complexes, and inhibitory effect on phagocytosic activity in spleen. The elevated specific humoral antibody response against SRBC suggested a possible compensatory effect of the humoral immune system induced by stressful $\mathrm{Cd}$ conditions, which occurred during a long term of $\mathrm{Cd}$ administration before chicken immunisation by SRBC.

A different effect of dietary $\mathrm{AA}(100)$ and $\mathrm{AA}(1000)$ on chicken immune response was found, which also differed in healthy and Cd-immunocompromised chickens. The $\mathrm{AA}(100)$ dosage led to correction of immune system response and increased tolerance of chickens to subtoxic $\mathrm{Cd}$ intake due to its antioxidative effect. The AA(1000) dosage either caused no significant shift in immunological indices or manifested a synergistic effect combined with $\mathrm{Cd}$, exacerbating the adverse effect of this toxic element exerting the prooxidative effect. The modulative effect of dietary AA probably is not restricted to direct antioxidative action on $\mathrm{Cd}$-induced free radicals in tissues. Perhaps, the interaction of AA and other vitamins, for example vitamins of the B group, also took place. Some scientific reports have shown the role of vitamin $\mathrm{C}$ on utilization and absorption of folic acid $\left(\mathrm{B}_{9}\right)$ in Japanese Quail (Sahin et al., 2003). Vitamin C converts the inactive form of folic acid to its active form. The authors showed that normal dietary supplements of vitamin $\mathrm{C}$ and folic acid act as antioxidants and synergists against oxidative stress. However, a high dietary dose of vitamin $C$ has a very large effect. The ingestion of megadoses of L-ascorbic acid may inactivate vitamin $\mathrm{B}_{12}$ and cause its deficiency by destroying the cobalamins (Hogenkamp, 1980; Mix, 1999). Without sufficient quantity of vitamin $\mathrm{B}_{12}$, the activation of folic acid may be compromised, causing the promotion of oxidative processes. Thus, it can be supposed that the interaction between vitamin $C$ in a high dose and vitamins $B_{12}$ and $B_{9}$ may also induce an increase of oxidative stress. The investigation of interaction of these vitamins during $\mathrm{Cd}$ exposure in chickens may be of interest in our future experiments. The results of our present study demonstrated that, for healthy $\mathrm{Cd}$-unreated chickens, AA(100) appeared to cause substantial immunostimulative action, while $\mathrm{AA}(1000)$ had a slight or no effect.

\section{AKNOWLEDGEMENTS}

The study was supported by grant No. 05. 1452 and No. 09.1350 from the Latvian Council of Science.

\section{REFERENCES}

Anonīms (2003). www.lpc.gov.lv/download/kadmijs.doc.

Anonymous (1984). International Life Sciences Institute. The selection of doses in chronic toxicity and carcinogenecity studies (pp. 9-49). In: Current Issues in Toxicology. Grict, H.C. (ed). New York: Springer Verlag.

Beisel, W.R. (1982). Single nutrients and immunity. Amer. J. Clin. Nutr., 35, 417-468.

Berzina, N., Apsite, M., Basova, N., Smirnova, G., Isajevs, S. (2008). Influence of different dietary ascorbic acid levels and storage of iron on oxidative stability in chicken tissues (pp. 867-872). In: $1^{\text {st }}$ Mediterranean Summit of WPSA. Advances and Challenges in Poultry Science. Book of Proceedings, 7-10 May 2008, Porto Carras, Chalkidiki.

Berzina, N., Vasilyeva, S., Basova, N., Apsite, M. (2005). Dietary ascorbic acid supplementation: The good and the bad (pp. 301-304). In: Vitamine und Zusatzstoffe in der Ernährung von Mensch und Tier, 10. Symposium, 28. und 29. September, 2005 Friedrich-Schiller-Universität, Jena/ Türingen.

Bokori, J., Fekete, S. (1995). Complex study of the physiological role of cadmium. I. Cadmium and physiolgical role. Acta Vet. Hung., 43(1), 3-43.

Butcher, G.D., Miles, R.D. (2002). Interrelationship of nutrition and immunity. http://edis.ifas.ufl.edu

Chan, D.Y., Fry, N., Waisberg, M., Black, W.D., Hale, B.A. (2004). Accumulation of dietary cadmium $(\mathrm{Cd})$ in rabbit tissues and excretions: A comparison of lettuce amended with soluble $\mathrm{Cd}$ salt and lettuce with plant-incorporate Cd. J. Toxicol. Environ. Health, 67(5), 397-411.

Chowdhury, B.A., Friel, J.K., Chadra, R.K. (1987). Cadmium-induced immunopathology is prevented by zinc administration in mice. J. Nutr., 117, 1788-1794.

Close, B., Banister, K., Bemoth, E.-M., Bromage, N., Bunyan, J., Erhardt, W., Flecknell, P., Gregory, N., Hackbarth, M., Morton, D., Warwick, C. (1997). Recommendation for euthanasia of experimental animals: Part 2. Lab. Anim., 31(1), 1-37.

Čekstere G. (2011). Vides faktoru ietekme uz Holandes liepu (Tilia vulgaris) vitalitāti Rīgas ielu apstādījumos (promocijas darbs) [Effect of environmental factors on the vitality of Common Lime (Tilia vulgaris) in Rìga street greeneries (promotional work)]. Rīga: LU Akadēmiskais apgāds. 225 lpp.

El-Demerdash, F.M., Yousef, M.I., Kedwany, F.S., Baghdady, H.H. (2004). Cadmium-induced changes in lipid peroxidation, blood hematology, bio- 
chemical parameters and semen quality of male rats: Protective role of vitamin E and $\beta$-carotene. Food and Chem. Tox., 42(10), 1563-1571.

Fairbrother, A., Smits, J., Grasman, K.A. (2004). Avian immunotoxicology. J. Tox. Environ. Health, Part 2, 7(2), 105-137.

Fox, M.R.S. (1979). Nutritional influences on metal toxicity: Cadmium as a model toxic element. Environ. Health Persp., 29, 95-104.

Fox, M.R.S., Fry, B.E., Jr. (1970). Cadmium toxicity decreased by dietary L-ascorbic acid supplements. Science, 169, 989-991.

Friemel, H. (ed.) (1976). Immunologische Arbeitsmethoden. Jena: VEB Gustav Fischer Verlag. 518 S.

Hill, C.H. (1979). Dietary influences on resistance to salmonella infection in chicks. Fed. Proc., 38, 2129-2133.

Hogenkamp, H.P.C. (1980). The interaction between vitamin $\mathrm{B}_{12}$ and vitamin C. Amer. J. Clin. Nutr., 33, 1-3.

Hutton, M. (1983). Sources of cadmium in the enviroment. Ecotox. Environ. Saf., 7(1), 9-24.

Järup, L., Berglund, M., Elinder, C.G., Nordberg G., Valter M. (1998). Health effects of cadmium exposure. A review of the literature and a risk estimate. Scand. J. Work Environ. Health, 24(1), 1-51.

Järup, L. (2003). Hazards of heavy metal contamination. Brit. Med. Bull., 68, $167-182$.

Jones, R.H., Williams, R.L., Jones, A.M. (1971). Effects of heavy metal on the immune response. Preliminary findings for cadmium in rats. Proc. Soc. Exp. Biol. Med., 137, 1231-1236.

Khanna, S.S., Karjodkar, F.R. (2006). Circulating immune complexes and trace elements (copper, iron and selenium) as markers in oral precancer and cancer: A randomised, controlled clinical trial. http://www.head-face-med-com/content/2/1/33.

Maxwell, M.H. and Robertson, G.W. (1998). The avian heterophil leukocyte: A review. World's Poultry Sci. J., 54(2), 155-178.

Mix D.M.D., J.A. (1999). Do megadoses of vitamin C compromise folic acid's role in the metabolism of plasma homocysteine? Nutr. Res., 19(2), $161-165$

Mochizuki, M., Hondo, R., Kumon, K., Sasaki, R., Matsuba, H., Ueda, F. (2002). Cadmium contamination in wild birds as an indicator of environmental pollution. Environ. Monitor. Asses., 73, 229-235.

Ogungbe, I.V., Lawal, A.O. (2008). The protective effects of ethanolic extract of garlic and ascorbic acid on cadmium-induced oxidative stress. J. Biol. Sci., 8(1), 181-185.

Riha, J. (1979). The use of polyethylenglycol for immune complex detection in human sera. Immunol., 16, 489.
Sahin K., Onderci M., Sahin N., Gursu M.F., Kucuk O. (2003). Dietary vitamin $\mathrm{C}$ and folic acid supplementation ameliorates the detrimental effects of heat stress in Japanese quail. J. Nutr., 133, 1882-1886.

Sant'Ana, M.G., Moraes, R., Bernardi, M.M. (2005). Toxicity of cadmium in Japanese quail: Evaluation of body weight, hepatic and renal function, and cellular immune response. Environ. Res., 99(2), 273-277.

Satoh, M., Koyama, H., Kaji, T., Kito, H., Tohyama, C. (2002). Perspectives on cadmium toxicity research. Tohoku J. Exp. Med. 196, 23-32.

Sellin, M.K., Eidem T.M., Kolok, A.S. (2007). Cadmium exposures in fathead minnows: Are there sex-specific differences in mortality, reproductive success, and $\mathrm{Cd}$ accumulation? Arch. Environ. Contam. Toxicol., 52, 535-540.

Shugar D. (1952). Enzymatic assay of lysozyme. Biochim. Biophys. Acta, 8, 302-309.

Stankova, L., Gerhardt, N.B., Nagel, L., Bigleyu, R.H. (1975). Ascorbate and phagocyte function. Infect. Immun., 12, 252-256.

Stohls, S.J., Bagchi, D., Hassoun, E., Bagchi M. (2000). Oxidative mechanisms in the toxicity of chromium and cadmium ions. J. Environ. Pathol. Toxicol. Oncol. 19, 201-213.

Surai, P.F. (2003). Natural Antioxidants in Avian Nutrition and Reproduction. Nottingham University Press, Nottingham, England. 615 p.

Thomas, W.R., Holt P.G. (1978). Vitamin C and immunity: An assessment of the evidence. Clin Exp. Immunol., 32, 370-379.

Turgeon, M.L. (2003). Immunology and Serology in Laboratory Medicine. Third edition. Boston, Massachusets: Mosby. 557 p.

Vasilyeva, S., Berziņa, N., Apsite, M., Basova, N. (2004). Tissue accumulation of cadmium results in functional disturbunces in chicken organs of immunity (pp. 63-68). In: Macro and Trace Elements, Mengen- und Spurenelemente: $22^{\text {nd }}$ Workshop, September, $24^{\text {th }}$ and $25^{\text {th }}$ 2004. Jena: Friedrich Shiller University; Leipzig: Shubert-Verlag.

Yu, J. Y-L. (1994). Cellular defences against damage from reactive oxygen spieces. Physiol. Rev., 74, 139-162.

Вальдман А.P. (1977). Витамины в животноводстве [Vitamins in Animal Husbandry]. Рига: Зинатне. 352 с. (in Russian).

Васильева С., Берзиня Н., Ремез И. (2001). Комплекс методов для оценки воздействия кадмия и цинка на иммунитет птицы. Методы оценки иммунитета у птиц [Complex of methods for the estimation of cadmium and zinc action of chicken immunity. Methods of estimation of chicken immunity]. Baltic J. Lab. Anim. Sci., 11, 149-159 (in Russian).

Федосеева В.Н., Порядин Г.В., Ковальчук Л.В., Чередеев А.И., Каган В.Ю. (1993). Руководство по иммунологическим и аллергологическим методам в гигиенических исследованиях [Guidance of Immunologic and Allergologic Methods in Hygienic Research]. Москва, "ПРОМЭДОК”. 230 c. (in Russian).

Received 5 July 2011

\section{ASKORBĪNSKĀBES KĀ BARĪBAS PIEDEVAS IZRAISITTĀS IMŪNATBILDES MODULĀCIJAS VESELIEM UN KADMIJA IMŪNKOMPROMITĒTIEM CĀḶIEM}

Pētītas smagā metāla kadmija (50 mg uz $1 \mathrm{~kg}$ barības) izraisītās imunoloǵiskās izmaiṇas 1-30 dienu vecu cāḷu organismā. Vienlaicīgi pētījumā novērtēts barībai pievienoto divu askorbīnskābes devu (100 un 1000 mg uz 1 kg) modulējošais efekts. Eksperimentā konstatēts, ka ilgstoša (30 dienas) kadmija ievadīsana izraisīja cāḷ dzīvās masas samazināšanos un imūnatbildes traucējumus kā nespecifiskā, tā arī specifiskā līmenī. Abu eksperimentālo askorbīnskābes barības devu (100 un $1000 \mathrm{mg} / \mathrm{kg})$ ietekmes efekti uz cāḷu organismu ir atškirīgi. Askorbīnskābes deva $100 \mathrm{mg} / \mathrm{kg}$ (antioksidatīva ietekme) uzrādīja imūnstimulējošu efektu cāḷu organismā, kuri nesaṇ̄ma kadmiju, un koriǵéjošu efektu ar subtoksisku kadmija devu imūnkompromitētiem putniem. Tas liecina par organisma tolerances palielināšanos. Lielā askorbīnskābes deva $(1000 \mathrm{mg} / \mathrm{kg})$ barībā praktiski neietekmēja veselo cāḷu imunatbildi un demonstrēja vāju vai ar kadmiju sinerğisku efektu, saistītu ar askorbīnmskābes prooksidatīvo darbību. 